\title{
Protein interactions of the transcription factor Hoxa1
} Barbara Lambert ${ }^{1}$, Julie Vandeputte ${ }^{1}$, Sophie Remacle ${ }^{1}$, Isabelle Bergiers ${ }^{1}$, Nicolas Simonis ${ }^{2}$, Jean-Claude Twizere ${ }^{3}$,
Marc Vidal ${ }^{4,5}$ and René Rezsohazy ${ }^{*}$

\begin{abstract}
Background: Hox proteins are transcription factors involved in crucial processes during animal development. Their mode of action remains scantily documented. While other families of transcription factors, like Smad or Stat, are known cell signaling transducers, such a function has never been squarely addressed for Hox proteins.

Results: To investigate the mode of action of mammalian Hoxa1, we characterized its interactome by a systematic yeast two-hybrid screening against $\sim 12,200$ ORF-derived polypeptides. Fifty nine interactors were identified of which 45 could be confirmed by affinity co-purification in animal cell lines. Many Hoxa1 interactors are proteins involved in cell-signaling transduction, cell adhesion and vesicular trafficking. Forty-one interactions were detectable in live cells by Bimolecular Fluorescence Complementation which revealed distinctive intracellular patterns for these interactions consistent with the selective recruitment of Hoxa1 by subgroups of partner proteins at vesicular, cytoplasmic or nuclear compartments.
\end{abstract}

Conclusions: The characterization of the Hoxa1 interactome presented here suggests unexplored roles for Hox proteins in cell-to-cell communication and cell physiology.

Keywords: Hox, Hoxa1, ORFeome, Interactome

\section{Background}

The conserved family of homeodomain Hox transcription factors is critically involved in patterning the body plan of bilaterian embryos by controlling multiple morphogenetic and organogenetic processes during animal development [1-4]. Modifications in Hox protein expression and activity have likely contributed to the evolutionary diversification of animal forms [5,6]. Misregulation or mutation of several Hox proteins has been associated with pathologies like cancer or neuropathies $[7,8]$.

Hox proteins are transcription factors which regulate expression of target genes and chromatin remodeling [9]. A handful of proteins that interact with Hox proteins have been identified so far, and these are almost exclusively transcription factors, like the well-characterized Three Amino acid Loop Extension (TALE) homeodomain proteins Pbx/Exd and Prep/Meis/Hth [10], TFIIE $\beta$

\footnotetext{
* Correspondence: rene.rezsohazy@uclouvain.be

${ }^{1}$ Molecular and Cellular Animal Embryology group, Life Sciences Institute (ISV), Université Catholique de Louvain, Louvain-la-Neuve 1348, Belgium Full list of author information is available at the end of the article
}

[11], TATA Binding Protein (TBP) [12], Gli3 [13], Maf [14], Smad [15,16], High Mobility Group protein 1 (HMG1) [17], or transcriptional coregulators like CREB Binding Protein (CBP)/p300 [18-20]. Hox proteins may also form complexes with the translation initiation factor eIF4E to control the translation of target mRNAs [21]. Some Hox-like homeodomain proteins can be secreted into the extracellular compartment and translocate through the cell membrane to gain access to the cytosol and nucleus of neighboring cells, so it has been proposed that Hox proteins could display a paracrine transcriptional activity [22,23].

Numerous transcription factors, involved in critical developmental processes, like Smad, STAT, $\beta$-catenin or $\mathrm{NF} \kappa \mathrm{B}$, are primarily signal transducers. Though primarily cytoplasmic, upon activation these can translocate to the nucleus, where they convey signaling by affecting gene regulation. As signal transducers these transcription factors can interact with enzymatically active membrane receptors, adaptor proteins, signal transducing kinases, or ubitiquin ligases. Possibly, Hox transcription factors could similarly fulfill pivotal roles at the heart of

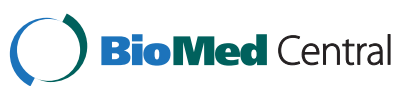


developmental processes, acting at the crossroads between cell-to-cell communication and cell fate determination. To our knowledge no exhaustive interaction screen has been performed to detect functional connections for a Hox protein.

Here, we conducted a proteome-wide screening for candidate interactors of Hoxa1. Hoxa1 is one of the earliest Hox genes to be expressed during embryonic development. It is involved in hindbrain segmentation and patterning $[1,24,25]$. Hoxa1 misregulation has been associated with mammary carcinogenesis [26]. We used a stringent high-throughput yeast two-hybrid (Y2H) approach to systematically test pairwise combinations, using Hoxa1 both as a bait and as a prey against the human ORFeome v3.1 resource, which contains 12,212 ORFs representing 10,214 genes [27]. Of the 59 Hoxa1 interactions identified, 45 could be validated by in vivo affinity binding assays in co-transfected animal cells. A striking subset of the validated interactors are not proteins involved in gene regulation. Rather, these interactors are adaptor proteins or modulators of the Bone Morphogenetic Proteins (BMP)/Tumor Growth Factor (TGF) $\beta$, Tumor Necrosis Factor (TNF), ReceptorTyrosine Kinases (RTK) and integrins signal transduction pathways. Other interactors participate in cell adhesion or endosomal trafficking. We detected 41 interactions in live cells by Bimolecular Fluorescence Complementation (BiFC). Depending on the different proteins identified, interactions either take place in the cytoplasm, in the nucleus, in association with vesicles or show a variable pattern from cell to cell, underscoring a dynamic interplay with Hoxa1. Numerous identified Hoxa1 partners reported to interact with each other within known pathways share similar intracellular patterns of Hoxa1 interaction by BiFC. We conclude that Hoxa1 can contact several subunits of multi-molecular functional platforms involved in cell signaling, cell-adhesion, or cell shape regulation.

\section{Results}

A proteome-wide yeast two-hybrid screening for Hoxa1 interactors

The yeast two-hybrid $(\mathrm{Y} 2 \mathrm{H})$ is a powerful approach for large-scale screenings to identify binary protein-protein interactions $[28,29]$. DB-Hoxa1 was tested pairwise against 12,212 open reading frame (ORF)-derived proteins from the human ORFeome version 3.1 [27] fused to the Gal4 activation domain (AD). In this configuration, we detected 40 distinct interactions (Table 1). We also screened in the other configuration, Hoxa1 as a prey (AD-Hoxa1) against the full hORFeome in fusion with the Gal4 DB. In the second configuration we detected 28 interactions, of which 8 were also detected in the DBHoxa1/AD-ORFs configuration (Table 2). A total of 59 candidate Hoxa1 interactors were identified. We found the Hoxa1 homodimerization interaction and 8 out of the 9 Hoxal interactions, previously described in the literature [28,30] (Table 1 and 2).

\section{Co-purification from animal cells validate forty-five Hoxa1 interactors}

To validate the 59 interactions identified by the $\mathrm{Y} 2 \mathrm{H}$ screen by an orthogonal assay we turned to affinity copurification of a FLAG-Hoxa1 fusion protein co-expressed with glutathione S-transferase (GST)-tagged candidate interactors in transfected COS7 or HEK293T cells. In absence of GST-partners, there was no or very weak background binding of FLAG-Hoxa1 onto the glutathioneagarose beads (Figure 1). As positive controls we measured Hoxa1 dimer formation [30,31] and the reproducible interaction between Hoxa1 and Pbx1a [32] (Figure 1). In total, affinity co-purification from cotransfected cells confirmed 45 out of the $59 \mathrm{Y} 2 \mathrm{H}$ interactors (Table 1 and 2), in the presence of which a detectable amount of FLAG-Hoxa1 remained associated to the GST-fusion/glutathione-agarose beads and could be detected on western blots. It should be noted however that some interactions could not be confirmed because the corresponding GST-ORF fusion was expressed at an undetectable level, if at all (data not shown).

\section{Bioinformatics functional analysis}

To determine if Hoxa1 preferentially targets particular biological functions or pathways, we tested for statistical enrichment in regards to the Gene Ontology GO [33]), Kyoto Encyclopedia of Genes and Genomes KEGG; [34]) and Pathway Commons databases (www. pathwaycommons.org).

We observed that six GO terms were significantly overrepresented (Table 3). These enriched annotations are consistent with known functions of Hoxa1, linking our set of interactors to developmental and transcription factor function. There were several additional enriched, though not statistically so, GO terms linked to development and transcription factors (Table 3).

The immediate interactors of Hoxa1 were not enriched for annotated pathways, which could be due to incomplete coverage or relative sensitivity of the $\mathrm{Y} 2 \mathrm{H}$ assay [35], or be intrinsic to the way Hoxal interacts with pathways, needing only one or few direct contacts. To account for the latter possibility, we also analyzed second-degree interactors, proteins that interact with Hoxa1 targets. Proteins associated with 21 pathways are overrepresented compared to random expectation (Table 4), showing that Hoxa1 could play a role in various processes other than gene regulation, such as focal adhesion, axon guidance or several signaling cascades. 
Table 1 Interaction partners for Hoxa1 revealed by yeast two-hybrid screening using DB-Hoxa1

\begin{tabular}{|c|c|c|c|c|c|c|}
\hline Protein symbol & Protein name & Gene ID & $\begin{array}{l}\text { UniProtKB/ } \\
\text { Swiss-Prot }\end{array}$ & Protein function & BiFC signal & $\begin{array}{l}\text { Confirmed by } \\
\text { co-purification }\end{array}$ \\
\hline ADAMTSL4 (TSRC1) & ADAMTS-like 4 & 54507 & Q6UY14 & TNF-induced apopotosis & Nuclear & Y \\
\hline BAT2L & HLA-B associated transcript 2-like & 84726 & Q5JSZ5 & Unknown & Nuclear & Y \\
\hline C1orf94 & chromosome 1 open reading frame 94 & 84970 & Q6P1W5 & Protein binding & Cytoplasmic & Y \\
\hline CCDC33 & coiled-coil domain containing 33 & 80125 & Q8N5R6 & Protein binding & / & $\mathrm{N}$ \\
\hline EFCAB4B & EF-hand calcium binding domain 4B & 84766 & Q9BSW2 & Calcium binding & Nuclear, and vesicular & Y \\
\hline EFEMP $2 * S$ & $\begin{array}{l}\text { EGF-containing fibulin-like extracellular } \\
\text { matrix protein } 2\end{array}$ & 30008 & O95967 & Fibulin-like, unknown & n.d. & Y \\
\hline FAM154A & $\begin{array}{l}\text { family with sequence similarity } 154, \\
\text { member } A\end{array}$ & 158297 & Q8IYX7 & Unknown & Nuclear, vesicular, cytoplasmic & Y \\
\hline FHL5 (ACT) & four and a half LIM domains 5 & 9457 & Q5TD97 & $\begin{array}{l}\text { Transcription factor (zinc finger), } \\
\text { and kinesin and actin-binding protein }\end{array}$ & Nuclear & Y \\
\hline GPRIN2 & $\begin{array}{l}\text { G protein regulated inducer of neurite } \\
\text { outgrowth } 2\end{array}$ & 9721 & O60269 & G protein interaction & / & $\mathrm{N}$ \\
\hline $\mathrm{HOXA} 1^{\S}$ & homeobox A1 & 3198 & P49639 & Transcription factor (homeodomain) & Nuclear & Y \\
\hline HOXD3 & homeobox D3 & 3232 & P31249 & Transcription factor (homeodomain) & Nuclear & Y \\
\hline HSFY1 & heat shock transcription factor, Y-linked 1 & 86614 & Q96L16 & Transcription factor (heatshock factor) & / & N \\
\hline KRTAP26-1 ${ }^{\S}$ & keratin associated protein 26-1 & 388818 & Q6PEX3 & Keratin associated & Nuclear & Y \\
\hline KRTAP3-2 $2^{\S}$ & keratin associated protein 3-2 & 83897 & Q9BYR7 & Keratin associated & Nuclear & Y \\
\hline KRTAP3-3 $3^{\S}$ & keratin associated protein 3-3 & 85293 & Q9BYR6 & Keratin associated & / & $\mathrm{N}$ \\
\hline KRTAP4-12*\$ & keratin associated protein 4-12 & 83755 & Q9BQ66 & Keratin associated & Cytoplasmic & Y \\
\hline LGALS13 & lectin, galactoside-binding, soluble, 13 & 29124 & Q9UHV8 & $\begin{array}{l}\text { Lipase activity, signaling (regulator of } \\
\text { protein kinases) }\end{array}$ & Nuclear, vesicular, cytoplasmic & Y \\
\hline LNX2 & ligand of numb-protein $\times 2$ & 222484 & Q8N448 & $\begin{array}{l}\text { Molecular scaffold, E3 ubiquitin ligase, } \\
\text { signaling regulator (Notch), associated } \\
\text { to cell adhesion molecules }\end{array}$ & Nuclear and cytoplasmic & Y \\
\hline LPXN* & leupaxin & 9404 & O60711 & $\begin{array}{l}\text { Signaling (focal adhesion), Transcription } \\
\text { factor }\end{array}$ & Vesicular and cytoplasmic & Y \\
\hline MGAT5B (GnT-VB) & $\begin{array}{l}\text { mannosyl (a-1,6-)-glycoprotein } \beta-1,6-\mathrm{N} \text {-acetyl- } \\
\text { glucosaminyltransferase, isozyme B }\end{array}$ & 146664 & Q3V5L5 & $\begin{array}{l}\text { Glycosyltransferase, focal adhesion } \\
\text { dynamics }\end{array}$ & Nuclear & Y \\
\hline N4BP2L2 (PFAAP5) & NEDD4 binding protein 2-like 2 & 10443 & Q92802 & Transcription factor or co-regulator & Nuclear & Y \\
\hline NR4A1 (Nur77) & $\begin{array}{l}\text { nuclear receptor subfamily } 4 \text {, group } A \text {, } \\
\text { member } 1\end{array}$ & 3164 & P22736 & $\begin{array}{l}\text { Transcription factor (nuclear hormone } \\
\text { receptor) }\end{array}$ & / & $\mathrm{N}$ \\
\hline OGT & $\begin{array}{l}\text { O-linked N-acetylglucosamine (GlcNAc) } \\
\text { transferase }\end{array}$ & 8473 & 015294 & $\begin{array}{l}\text { Glycosyltransferase, transcription } \\
\text { co-regulator }\end{array}$ & Nuclear and cytoplasmic & Y \\
\hline $\mathrm{PCSK}^{\S}$ & $\begin{array}{l}\text { proprotein convertase subtilisin/kexin } \\
\text { type } 5\end{array}$ & 5125 & Q92824 & Pro-protein convertase & / & N \\
\hline
\end{tabular}


Table 1 Interaction partners for Hoxa1 revealed by yeast two-hybrid screening using DB-Hoxa1 (Continued)

\begin{tabular}{|c|c|c|c|c|c|c|}
\hline PDLIM7 (LMP-1) & PDZ and LIM domain 7 & 9260 & Q9NR12 & $\begin{array}{l}\text { Signaling regulator (BMP, IGFBP } \\
\text { pathways) }\end{array}$ & Cytoplasmic & Y \\
\hline PLSCR1* & phospholipid scramblase 1 & 5359 & 015162 & $\begin{array}{l}\text { Phospholipid scramblase, signaling } \\
\text { regulatior (receptor tyrosine kinases, } \\
\text { protein kinases), transcription factor }\end{array}$ & Nuclear & Y \\
\hline PLSCR4 ${ }^{\S}$ & phospholipid scramblase 4 & 57088 & Q9NRQ2 & $\begin{array}{l}\text { Phospholipid scramblase, transcription } \\
\text { factor }\end{array}$ & Nuclear & Y \\
\hline PRDM14 & PR domain containing 14 & 63978 & Q9G2V8 & Histone methyltransferase & Nuclear, vesicular, cytoplasmic & Y \\
\hline RBCK1 & $\begin{array}{l}\text { RanBP-type and C3HC4-type zinc finger } \\
\text { containing } 1\end{array}$ & 10616 & Q9BYM8 & $\begin{array}{l}\text { Signaling regulator (TNFR, protein } \\
\text { kinases), ubiquitin ligase, transcription } \\
\text { factor }\end{array}$ & Nuclear, vesicular, cytoplasmic & Y \\
\hline RBPMS (Hermes) & $\begin{array}{l}\text { RNA binding protein with multiple } \\
\text { splicing }\end{array}$ & 11030 & Q93062 & Signaling regulator (TGF $\beta$ ), RNA binding & Nuclear, vesicular, cytoplasmic & Y \\
\hline RGS17 & regulator of G-protein signaling 17 & 26575 & Q9UGC6 & Signaling regulator (G proteins) & / & N \\
\hline RGS20 & regulator of G-protein signaling 20 & 8601 & O76081 & $\begin{array}{l}\text { Signaling regulator (G proteins, } \\
\text { protein kinases) }\end{array}$ & Nuclear and cytoplasmic & Y \\
\hline SPRY1 & sprouty homolog 1 & 10252 & O43609 & $\begin{array}{l}\text { Signaling regulator (receptor } \\
\text { tyrosine kinases) }\end{array}$ & Nuclear, vesicular, cytoplasmic & Y \\
\hline SPRY2 & sprouty homolog 2 & 10253 & O43597 & $\begin{array}{l}\text { Signaling regulator (receptor tyrosine } \\
\text { kinases, protein kinases) }\end{array}$ & / & N \\
\hline TRAF1 & TNF receptor-associated factor 1 & 7185 & Q13077 & Signaling regulator (TNFR pathway) & Vesicular and cytoplasmic & Y \\
\hline TRAF2 & TNF receptor-associated factor 2 & 7186 & Q12933 & Signaling regulator (TNFR pathway) & Vesicular and cytoplasmic & Y \\
\hline TRIM23 (ARD1) & tripartite motif-containing 23 & 373 & P36406 & $\begin{array}{l}\text { Vesicular trafficking and signaling } \\
\text { regulator (TNF pathway), E3 ubiquitin } \\
\text { ligase }\end{array}$ & n.d. & Y \\
\hline TRIP6* & thyroid hormone receptor interactor 6 & 7205 & Q15654 & $\begin{array}{l}\text { Cytoskeleton and signaling regulator } \\
\text { (focal adhesion, TNFR), transcription } \\
\text { co-regulator }\end{array}$ & Nuclear & Y \\
\hline ZBTB16 (PLZF) & zinc finger and BTB domain containing 16 & 7704 & Q05516 & $\begin{array}{l}\text { Transcription factor (zinc finger), } \\
\text { signaling regulator (GPCR, ProRenin } \\
\text { Receptor) }\end{array}$ & Nuclear and vesicular & Y \\
\hline ZBTB32 (FAZF) & zinc finger and BTB domain containing 32 & 27033 & Q9Y2Y4 & Transcription factor (zinc finger) & Cytoplasmic & Y \\
\hline
\end{tabular}


Table 2 Interaction partners for Hoxa1 revealed by Y2H screening using AD-Hoxa1

\begin{tabular}{|c|c|c|c|c|c|c|}
\hline Protein symbol & Protein name & Gene ID & $\begin{array}{l}\text { UniProtKB/ } \\
\text { Swiss-Prot }\end{array}$ & Protein function & BiFC signal & $\begin{array}{l}\text { Confirmed by } \\
\text { co-purification }\end{array}$ \\
\hline ADCK4 & aarF domain containing kinase 4 & 79934 & Q96D53 & Ser/Thr kinase & I & N \\
\hline AGPAT1 & $\begin{array}{l}\text { 1-acylglycerol-3-phosphate } \\
\text { O-acyltransferase } 1\end{array}$ & 10554 & Q99943 & Acetyltransferase & / & $\mathrm{N}$ \\
\hline BSCL2 (Seipin) & $\begin{array}{l}\text { Berardinelli-Seip congenital } \\
\text { lipodystrophy } 2\end{array}$ & 26580 & Q96G97 & Unknown & / & $\mathrm{N}$ \\
\hline DKKL1 (Soggy) & dickkopf-like 1 & 27120 & Q9UK85 & Signaling modulator (Wnt pathway) & / & N \\
\hline EFEMP2*\$ & $\begin{array}{l}\text { EGF-containing fibulin-like } \\
\text { extracellular matrix protein } 2\end{array}$ & 30008 & O95967 & Fibulin-like, unknown & n.d. & Y \\
\hline FAM108A1 & $\begin{array}{l}\text { family with sequence similarity } 108, \\
\text { member } \mathrm{A} 1\end{array}$ & 81926 & Q96GS6 & unknown & Nuclear & Y \\
\hline GP9 & glycoprotein IX (platelet) & 2815 & P14770 & $\begin{array}{l}\text { Multifunctional receptor, cytoskeleton } \\
\text { and signaling regulator (integrins, focal } \\
\text { adhesion, PI3K) }\end{array}$ & / & $\mathrm{N}$ \\
\hline GRN* & granulin & 2896 & P28799 & $\begin{array}{l}\text { Growth factor, transcription factor } \\
\text { (in GRN precursor form) }\end{array}$ & n.d. & Y \\
\hline HOXA $1^{\S}$ & homeobox A1 & 3198 & P49639 & Transcription factor (homeodomain) & Nuclear & Y \\
\hline HSD3B7 & $\begin{array}{l}\text { hydroxy-delta-5-steroid dehydrogenase, } \\
3 \beta \text { - and steroid delta-isomerase } 7\end{array}$ & 80270 & $\mathrm{Q} 9 \mathrm{H} 2 \mathrm{~F} 3$ & Dehydrogenase & / & $\mathrm{N}$ \\
\hline IKZF2 (Helios) & IKAROS family zinc finger 2 & 22807 & Q9UKS7 & Transcription fator (zinc finger) & Nuclear & Y \\
\hline KRT81 & keratin 81 & 3887 & Q14533 & Intermediate filament & Nuclear and cytoplasmic & Y \\
\hline KRTAP26-1 ${ }^{\S}$ & keratin associated protein 26-1 & 388818 & Q6PEX3 & Keratin associated & Nuclear & Y \\
\hline KRTAP3-2 $2^{\S}$ & keratin associated protein 3-2 & 83897 & Q9BYR7 & Keratin associated & Nuclear & Y \\
\hline KRTAP3-3 $3^{\S}$ & keratin associated protein 3-3 & 85293 & Q9BYR6 & Keratin associated & / & N \\
\hline KRTAP4-12*§ & keratin associated protein 4-12 & 83755 & Q9BQ66 & Keratin associated & Cytoplasmic & Y \\
\hline KRTAP5-9 & keratin associated protein 5-9 & 3846 & P26371 & Keratin associated & Vesicular and cytoplasmic & Y \\
\hline LIMS1 (PINCH1) & $\begin{array}{l}\text { LIM and senescent cell antigen-like } \\
\text { domains } 1\end{array}$ & 3987 & P48059 & $\begin{array}{l}\text { Cytoskeleton and signaling regulator } \\
\text { (focal adhesion, integrins, receptor } \\
\text { tyrosine kinases) }\end{array}$ & Nuclear & Y \\
\hline $\mathrm{MDF}^{*}(\mathrm{I}-\mathrm{mfa})$ & MyoD family inhibitor & 4188 & Q99750 & $\begin{array}{l}\text { Signaling regulator (channels, Wnt, } \\
\text { JNK pathways) - Transcription factor } \\
\text { (I-mfa domain), }\end{array}$ & Nuclear, vesicular, cytoplasmic & Y \\
\hline PCSK5 $5^{\S}$ & $\begin{array}{l}\text { proprotein convertase subtilisin/kexin } \\
\text { type } 5\end{array}$ & 5125 & Q92824 & Pro-protein convertase & / & $\mathrm{N}$ \\
\hline PDCD6IP (Alix) & $\begin{array}{l}\text { programmed cell death } 6 \text { interacting } \\
\text { protein }\end{array}$ & 10015 & Q8WUM4 & $\begin{array}{l}\text { Endosome formation and vesicular } \\
\text { trafficking, cytoskeleton and signaling } \\
\text { regulator (Focal adhesion, TNFR pathway, } \\
\text { EGFR, PDGFR) }\end{array}$ & Vesicular and cytoplasmic & Y \\
\hline PFKM & phosphofructokinase, muscle & 5213 & P08237 & Glycolysis & / & N \\
\hline
\end{tabular}


Table 2 Interaction partners for Hoxa1 revealed by Y2H screening using AD-Hoxa1 (Continued)

\begin{tabular}{|c|c|c|c|c|c|c|}
\hline PITX2 & paired-like homeodomain 2 & 5308 & Q99697 & Transcription factor (homeodomain) & Nuclear & Y \\
\hline PLSCR4 ${ }^{\S}$ & phospholipid scramblase 4 & 57088 & Q9NRQ2 & $\begin{array}{l}\text { Phospholipid scramblase, transcription } \\
\text { factor }\end{array}$ & Nuclear & Y \\
\hline RAB33A & member RAS oncogene family & 9363 & Q14088 & $\begin{array}{l}\text { Small GTPase, vesicular trafficking } \\
\text { (Ras pathway) }\end{array}$ & Nuclear & Y \\
\hline SMOC1 & SPARC related modular calcium binding 1 & 64093 & Q9H4F8 & $\begin{array}{l}\text { Extracellular matrix protein, signaling, } \\
\text { migration and differentiation modulator }\end{array}$ & n.d. & Y \\
\hline TRAPPC6A* & trafficking protein particle complex $6 \mathrm{~A}$ & 79090 & O75865 & Vesicular trafficking & Nuclear & Y \\
\hline ZZZ3 & zinc finger, ZZ-type containing 3 & 26009 & Q8IYH5 & Transcription factor (zinc finger) & Nuclear & $\mathrm{Y}$ \\
\hline
\end{tabular}

* Previously reported by Rual et al., 2005.

${ }^{\S}$ Revealed by both AD-ORF and DB-ORF screening.

${ }^{a} \mathrm{Y}=$ yes; $\mathrm{N}=$ no. 


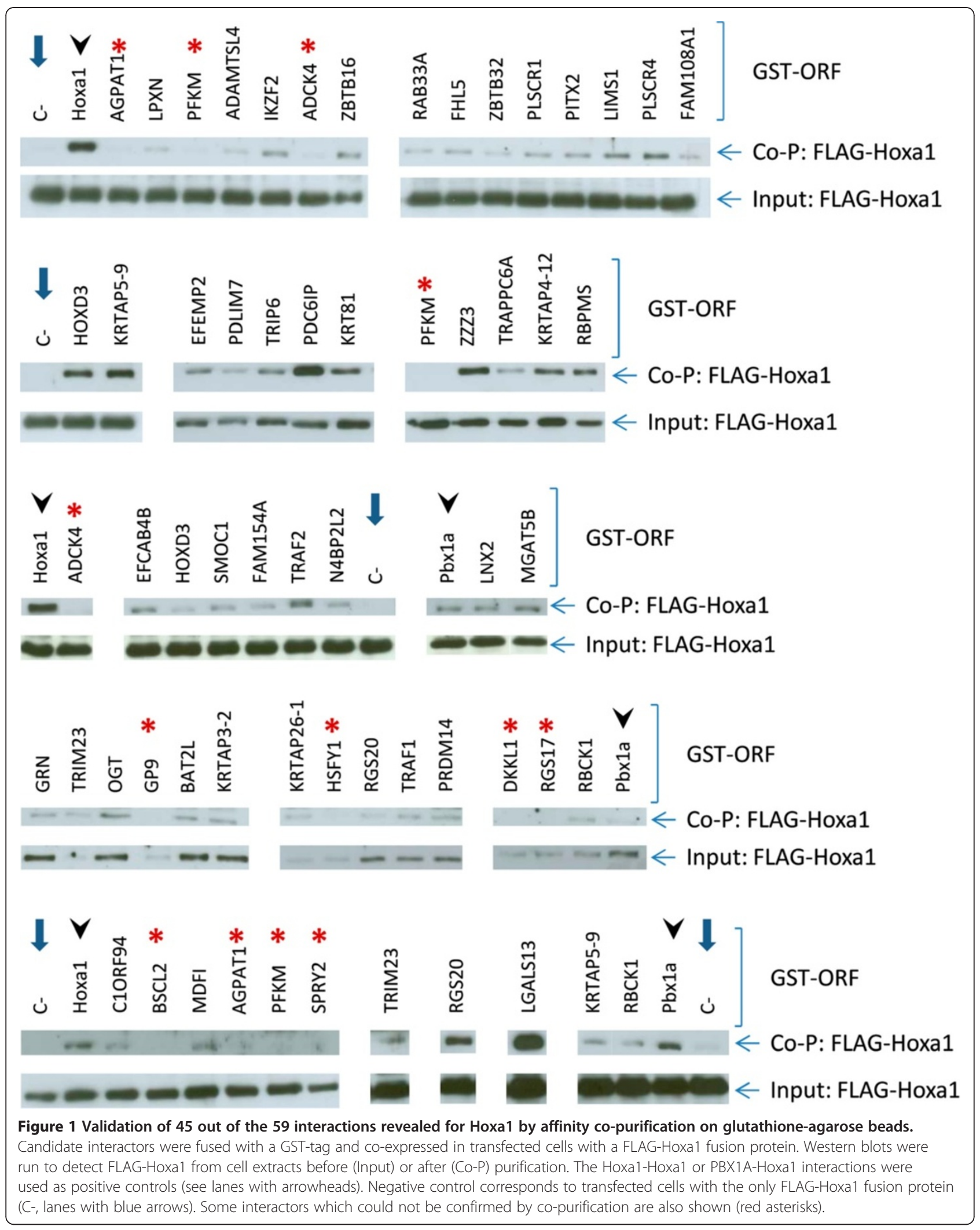


Table 3 Gene Ontology (GO) enrichment analysis

\begin{tabular}{lllll}
\hline GO term & Obs $^{*}$ & Odds ratio $^{\mathbf{S}}$ & P-value $^{\mathbf{f}}$ & Corr P-value $^{\mu}$ \\
\hline keratin filament & 6 & 102,352 & $3,62292 \mathrm{E}-10$ & $1,19194 \mathrm{E}-07$ \\
pattern specification process & 6 & 12,3435 & $2,01548 \mathrm{E}-05$ & 0,00331547 \\
regionalization & 5 & 14,3981 & 0,000048482 & 0,00531685 \\
cranial nerve morphogenesis & 2 & 116,248 & 0,000331888 & 0,0272978 \\
kidney development & 3 & 21,403 & 0,000559756 & 0,0306933 \\
zinc ion binding & 16 & 2,99882 & 0,000514454 & 0,0338511 \\
embryonic development & 6 & 5,58735 & 0,00120012 & 0,0564059 \\
receptor signaling protein serine/threonine kinase activity & 4 & 8,11769 & 0,00208634 & 0,0624006 \\
developmental process & 20 & 2,38882 & 0,00204634 & 0,0673246 \\
negative regulation of MAP kinase activity & 2 & 19,4953 & 0,00596027 & 0,0676182 \\
regulation of transcription factor import into nucleus & 2 & 31,8952 & 0,00251195 & 0,0688694 \\
cation binding & 19 & 2,14904 & 0,00649842 & 0,071266 \\
anterior/posterior pattern formation & 3 & 13,3725 & 0,00198155 & 0,0724365 \\
cytoskeletal part & 8 & 3,92527 & 0,00191605 & 0,0787977 \\
inner ear morphogenesis & 2 & 27,0115 & 0,00335617 \\
\hline
\end{tabular}

* number of Hoxa1 interactors annotated with the corresponding GO term.

$\$$ the odds ratio represents the enrichment of the corresponding GO term in the set of Hoxa1 interaction partners, an odds ratio of 10 meaning that the considered GO term is observed 10 times more than expected at random.

${ }^{£}$ probability to see at least the number of proteins corresponding to the $\mathrm{GO}$ term at random.

${ }^{\mu} \mathrm{P}$-value including a correction for multiple testing.

\section{Hoxa1-mediated interactions take place in distinct cell compartments}

We tested the 45 validated Hoxa1 interacting proteins by Bimolecular Fluorescence Complementation (BiFC) assay, which not only tests for protein interactions but can also visualize where the distinct interactions occur in live cells. For BiFC, the ORF corresponding to each interactor was fused C-terminally to the N-terminal 173 amino acids of the Venus fluorescent protein (VN173), while the Hoxa1 ORF was fused downstream of the Cterminal moiety of Venus (amino acids 155 to 243; VC155). Detectable fluorescence in cells transfected for the complementary VN173 and VC155 fusion proteins means that a functional Venus has been reconstituted, indicating that the partner proteins interact. As a preliminary control, BiFC was assayed for the well-established Hoxa1-PBX1A interaction (Figure 2). The VN173-PBX1A and VC155-Hoxa1 fusion proteins provided fluorescence complementation (Figure 2A), whereas the VN173-PBX1A/VC155 and VN173/VC155Hoxa1 combinations did not (Figure 2B, C). This therefore supported that the $\mathrm{N}$ - and C-terminal Venus fragments did not reassociate if not fused to interacting proteins. In addition, the immunocytolocalization of Venus consistently revealed that the VN173- and VC155-containing fusion proteins displayed a broad intracellular distribution that completely encompassed the narrower BiFC signal. In agreement with these controls, like the VN173-PBX1A fusion (Figure 2B), none of the VN173-interactor fusions provided fluorescence alone or in the presence of the VC155 Venus fragment alone (data not shown). For 41 out of the 45 interactors tested specific fluorescence was observed upon addition of the VC155-Hoxa1 fusion protein. Distinct patterns of intracellular interactions were observed (see Table 1 and 2, Figure 3). For 31 proteins, interactions took place in the nucleus (Figure $3 \mathrm{~A}$ and $\mathrm{C}$ ). Of these, 16 proteins appeared to contact Hoxa1 exclusively in the nucleus, while 15 also displayed other patterns of subcellular fluorescence complementation. Among the proteins found to bind Hoxa1 in the nucleus, some were known transcription factors (Table 5) or were known to have nuclear functions, but other were not (e.g. LGALS13, LIMS1, LNX2, MGAT5B, RBPMS, RAB33A, RGS20, TSCR1). A set of proteins shared a similar interaction pattern characterized by a diffuse, finely-punctuated cytoplasmic signal without nuclear staining (Figure 3B). This subcellular localization pattern was observed for different proteins reported to participate in a common signaling pathway. Examples are TRAF, TRIP or PDCD6IP (also known as Alix) which are found associated with the TNFR family of receptors [36-41], SPRY1 and PDCD6IP modulating RTK downstream signaling [42-46], PDLIM7 (alias LMP1) and RBPMS (also known as Hermes) which are involved in the BMP/TGF $\beta$ signaling regulation $[47,48]$ and $\mathrm{LPXN}$, PDCD6IP and TRIP6 known to associate with focal adhesion sites and related signal transduction [49-53]. As a control, in cells co-expressing GST-TRAF1 fusion and wildtype Hoxa1, proteins displayed an overlapping intracellular distribution 
Table 4 Pathways enriched in secondary Hoxa1 interactors

\begin{tabular}{|c|c|c|c|c|c|c|c|c|}
\hline Pathway name & ID* & $\mathrm{Obs}^{5}$ & Odds ratio $^{f}$ & $\mathrm{FDR}^{\mu}$ & Corr FDR ${ }^{\S}$ & Source & Gene symbols & Entrez gene IDs \\
\hline $\begin{array}{l}\text { RXR and RAR hetrodimerization with other } \\
\text { nuclear receptor }\end{array}$ & pc926 & 2 & 24,83 & $2,00 \mathrm{E}-05$ & $2,40 \mathrm{E}-03$ & $\mathrm{NCl}-\mathrm{Nature}$ & FAM120B,NR1H2 & 84498,7376 \\
\hline $\begin{array}{l}\text { Cell adhesion molecules (CAMs) - Homo sapiens } \\
\text { (human) }\end{array}$ & hsa04514 & 2 & 19,70 & $9,00 \mathrm{E}-05$ & 1,35E-02 & KEGG & CLDN2,PVRL2 & 9075,5819 \\
\hline Gap junction - Homo sapiens (human) & hsa04540 & 2 & 16,59 & $8,00 \mathrm{E}-05$ & $1,20 \mathrm{E}-02$ & KEGG & GNAI2,PDGFRB & 2771,5159 \\
\hline Signaling events mediated by PTP1B & pc948 & 4 & 12,72 & $1,00 \mathrm{E}-05$ & 1,20E-03 & $\mathrm{NCl}$-Nature & CRK,SPRY2,TRPV6,PDGFRB & $1398,10253,55503,5159$ \\
\hline Retinoic acid receptors-mediated signaling & pc960 & 3 & 10,19 & $2,10 \mathrm{E}-04$ & $2,52 \mathrm{E}-02$ & $\mathrm{NCl}-$ Nature & NR1H2,NRIP1,FAM120B & $7376,8204,84498$ \\
\hline Integrins in angiogenesis & pc989 & 3 & 10,04 & $3,40 E-04$ & 4,08E-02 & NCl-Nature & CDKN1B,SPP1,VCL & $1027,6696,7414$ \\
\hline Down-stream signal transduction & pc690 & 2 & 8,28 & $5,00 \mathrm{E}-05$ & $3,14 \mathrm{E}-02$ & Reactome & PDGFRB,NCK2 & 5159,8440 \\
\hline Signaling by PDGF & pc876 & 2 & 8,28 & $5,00 \mathrm{E}-05$ & $3,14 \mathrm{E}-02$ & Reactome & PDGFRB,NCK2 & 5159,8440 \\
\hline $\begin{array}{l}\text { Toll-like receptor signaling pathway - Homo sapiens } \\
\text { (human) }\end{array}$ & hsa04620 & 3 & 7,54 & $3,20 \mathrm{E}-04$ & $4,80 \mathrm{E}-02$ & KEGG & TRAF6,TOLLIP,SPP1 & $7189,54472,6696$ \\
\hline Homologous recombination - Homo sapiens (human) & hsa03440 & 2 & 7,18 & $1,40 \mathrm{E}-04$ & $2,10 \mathrm{E}-02$ & KEGG & TOP3B,RAD54B & 8940,25788 \\
\hline LPA receptor mediated events & pc1042 & 4 & 7,07 & $1,30 \mathrm{E}-04$ & $1,56 \mathrm{E}-02$ & NCl-Nature & BIRC2,TRIP6,TRAF6,CRK & $329,7205,7189,1398$ \\
\hline Focal adhesion - Homo sapiens (human) & hsa04510 & 8 & 6,55 & $3,00 \mathrm{E}-05$ & 4,50E-03 & KEGG & $\begin{array}{l}\text { SPP1,VCL,VASP,CRK,PDGFRB,BIRC2, } \\
\text { CCND3,PAK7 }\end{array}$ & $\begin{array}{l}6696,7414,7408,1398,5159,329 \\
896,57144\end{array}$ \\
\hline TCR signaling in naive CD4+ T cells & pc1031 & 4 & 6,54 & $3,00 \mathrm{E}-04$ & $3,60 \mathrm{E}-02$ & $\mathrm{NCl}-$ Nature & BIRC2,TRAF6,GRAP2,TRPV6 & $329,7189,9402,55503$ \\
\hline Axon guidance - Homo sapiens (human) & hsa04360 & 5 & 6,50 & $1,40 \mathrm{E}-04$ & $2,10 \mathrm{E}-02$ & KEGG & GNAI2,PAK7,NTN4,ABLIM1,NCK2 & $2771,57144,59277,3983,8440$ \\
\hline TCR signaling in naive CD8+ T cells & pc997 & 4 & 6,34 & 3,80E-04 & 4,56E-02 & $\mathrm{NCl}$-Nature & TRAF6,GRAP2,TRPV6,BIRC2 & $7189,9402,55503,329$ \\
\hline Lysine degradation - Homo sapiens (human) & hsa00310 & 3 & 6,28 & $1,00 \mathrm{E}-04$ & $1,50 \mathrm{E}-02$ & KEGG & OGDH,AASDHPPT,EHMT2 & $4967,60496,10919$ \\
\hline IGF1 pathway & pc1041 & 3 & 6,26 & $3,60 \mathrm{E}-04$ & $4,32 \mathrm{E}-02$ & $\mathrm{NCl}-\mathrm{Nature}$ & CRK,NCK2,YWHAE & $1398,8440,7531$ \\
\hline p75(NTR)-mediated signaling & pc978 & 5 & 6,02 & $2,60 \mathrm{E}-04$ & $3,12 \mathrm{E}-02$ & NCl-Nature & YWHAE,TRAF6,BIRC2,RTN4,LINGO1 & $7531,7189,329,57142,84894$ \\
\hline Proteogylcan syndecan-mediated signaling events & pc1045 & 5 & 5,53 & 2,20E-04 & 2,64E-02 & $\mathrm{NCl}-$ Nature & $\mathrm{BSG}, \mathrm{HGS}, \mathrm{CRK}, \mathrm{SPRY} 2, \mathrm{SPP} 1$ & $682,9146,1398,10253,6696$ \\
\hline Syndecan-1-mediated signaling events & pc974 & 3 & 5,46 & 1,60E-04 & $1,92 \mathrm{E}-02$ & $\mathrm{NCl}-$ Nature & $\mathrm{BSG}, \mathrm{CRK}, \mathrm{HGS}$ & $682,1398,9146$ \\
\hline Plasma membrane estrogen receptor signaling & pc1048 & 6 & 4,07 & 3,60E-04 & 4,32E-02 & NCl-Nature & CRK,SLC9A1,IRF4,NCK2,YWHAE,TRAF6 & $1398,6548,3662,8440,7531,7189$ \\
\hline
\end{tabular}

* pathway identifier.

$\$$ number of Hoxa1 interactors belonging to the corresponding pathway.

${ }^{f}$ the odds ratio represents the enrichment of the corresponding pathway, an odds ratio of 10 meaning that the considered pathway is observed 10 times more than expected at random.

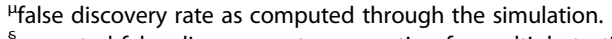

${ }^{8}$ corrected false discovery rate accounting for multiple testing. 


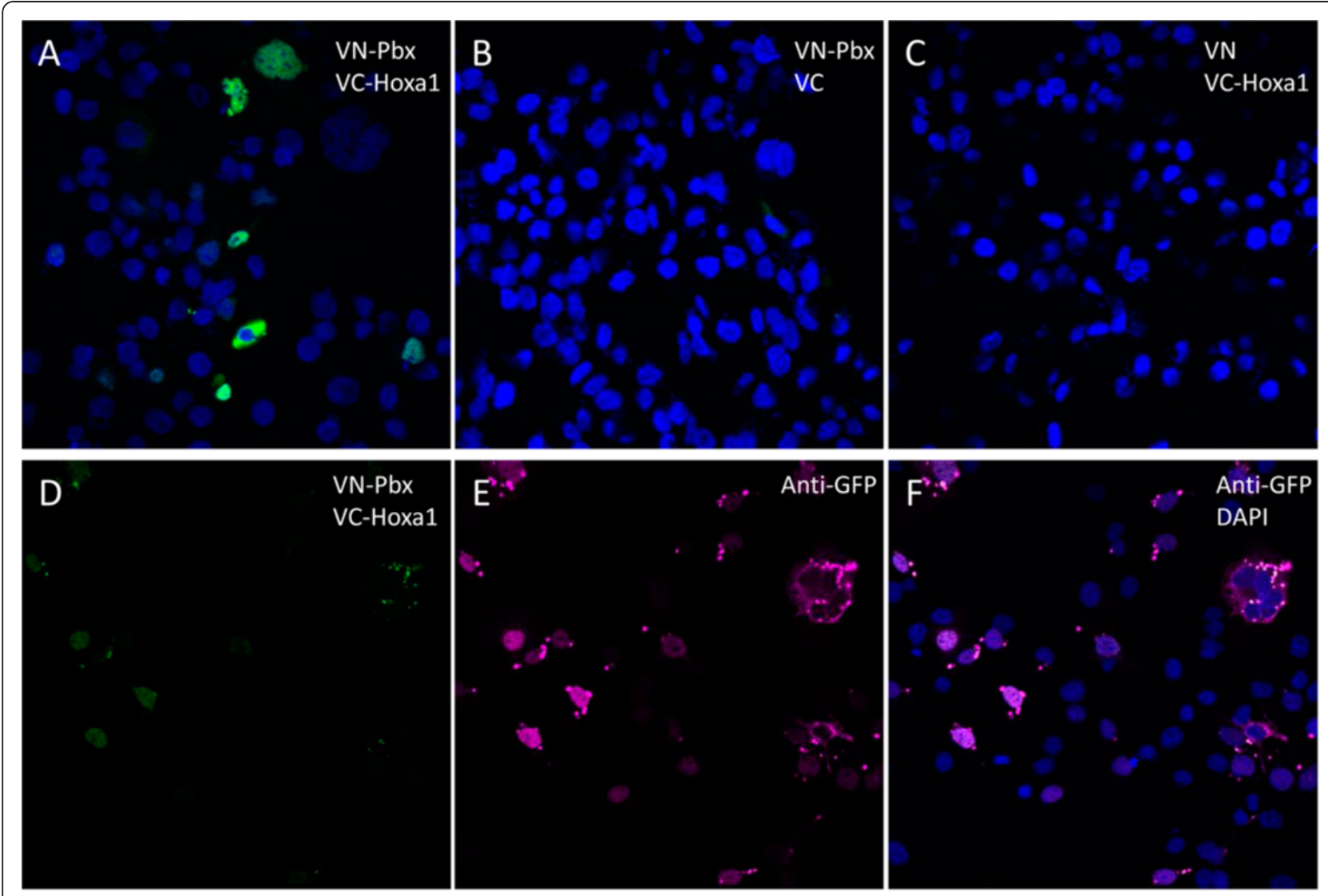

Figure 2 Bimolecular Fluorescence Complementation assay reveals the Hoxa1-PBX1A interaction in culture cells. COS7 cells were transfected with combinations of VN173, VN173-PBX1A, VC155 and VC155-Hoxa1 expression vectors. Upon interaction between PBX1A and Hoxa1, the VN173 and VC155 moieties of the Venus fluorescent protein brought together provide a fluorescent signal (A). Fluorescence complementation does not appear when the VN173 or VC155 fragments are expressed instead of the corresponding fusion proteins (B-C). As a control, expression of Venus fragments is detected by immunocytochemistry (anti-GFP). The BiFC signal shows colocalization with the anti-GFP immunofluorescence (D-F).

consistent with the BiFC signal observed with VN173TRAF1/VC155-Hoxa1 (Figure 4). Fourteen interactors tested displayed variable interaction patterns, showing mostly nuclear to nuclear and cytoplasmic or nuclear and vesicular BiFC signal (Figure $3 \mathrm{~A}$ and $\mathrm{C}$ ). This heterogeneous distribution suggests a coordinated shuttling between cell compartments for Hoxa1 and some partners (e.g. MDFI, OGT, PITX2, PRDM14, RBCK1, RBPMS, SPRY1, ZBTB16). The specific associations between Hoxa1 and 41 interactors detected by BiFC shows that Hoxa1 can associate dynamically with distinct categories of proteins in distinct intracellular domains.

\section{Discussion}

By a high-throughput $\mathrm{Y} 2 \mathrm{H}$ screen we identified 59 Hoxa1 interacting proteins among which 45 were confirmed by co-precipitation from animal cells. The intracellular localization of 41 interactions was further detected by a BiFC approach. This is the first exhaustive screen and analysis for interactors of a Hox protein. Our data support the conclusion that Hox proteins, and Hoxa1 in particular, known as crucial transcription factors controlling developmental processes can fulfill unexplored roles in cell signaling, cell adhesion, or vesicular trafficking.

Hoxa1 appears to interact with several proteins found to be part of molecular platforms associated with a few signaling pathways (TNFR superfamily, RTK, BMP/ TGF $\beta$, Focal adhesion,...), membrane dynamics and vesicular trafficking (Table 5). These platforms contact activated receptors at the plasma membrane and can positively or negatively modulate the downstream signaling or subsequent internalization in the endosomal compartment. By interacting with these proteins Hoxa1 could either act as a modulator or an effector of these signaling pathways. The BiFC assay revealed that most of the interactors involved in signaling pathways display a similar pattern of Hoxa1 interaction in culture cells. LPXN, PDLIM7, PDCD6IP, RBPMS, SPRY1, TRAF1, TRAF2 and TRIP6, for example, showed a BiFC signal 

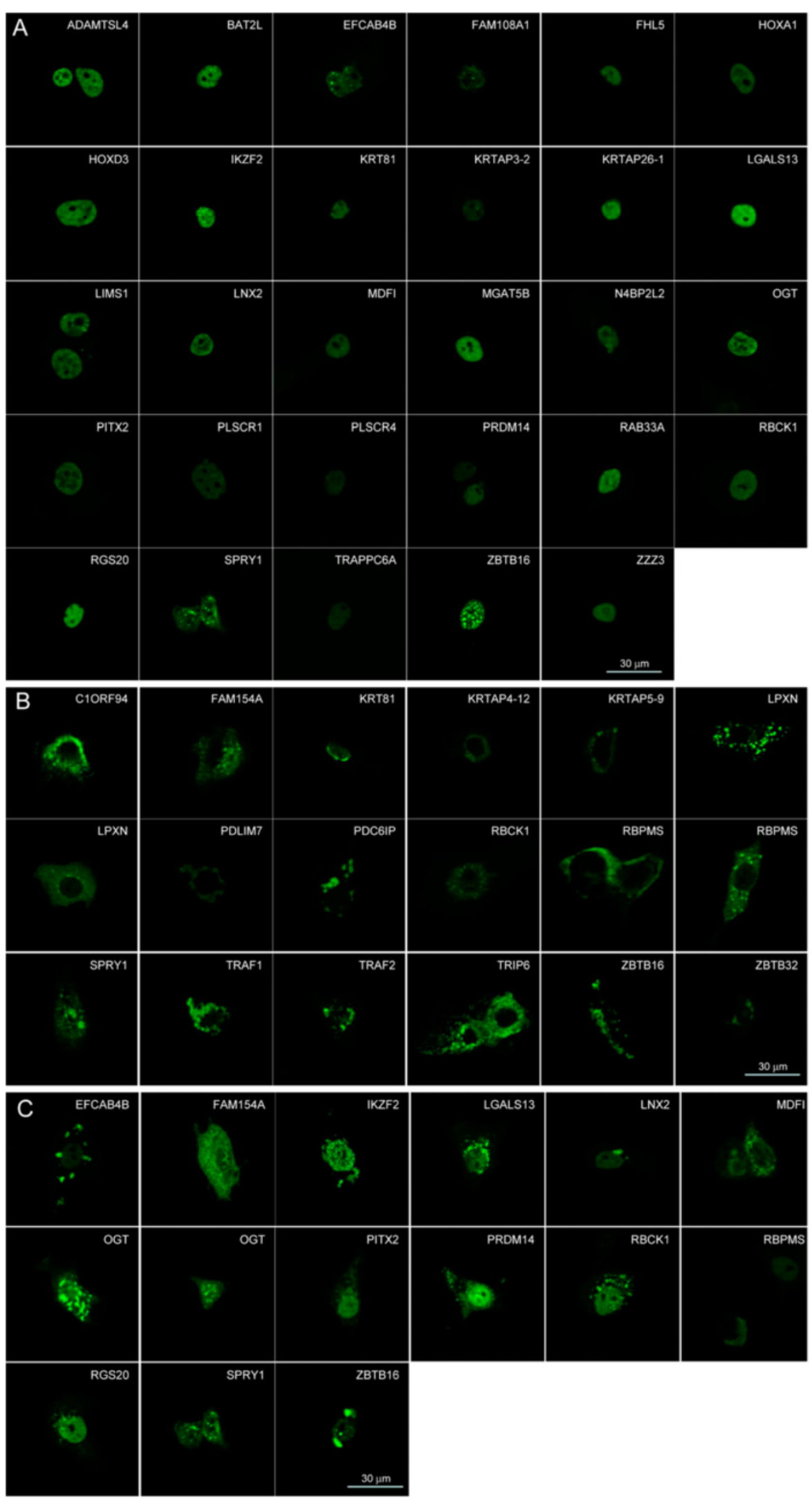

Figure 3 (See legend on next page.) 
(See figure on previous page.)

Figure 3 Bimolecular Fluorescence Complementation assay reveals the Hoxa1-mediated interactions in culture cells. MCF10A cells were transfected with VN173-hORF and VC155-Hoxa1 fusion proteins. Upon interaction between the partner proteins, the VN173 and VC155 moieties of the Venus fluorescent protein brought together provide a fluorescent signal. The interactions between Hoxa1 and its interactors can be classified according to their intracellular pattern: (A) nuclear, (B) cytoplasmic or associated to vesicles, (C) nuclear and cytoplasmic and/or vesicular.

in the cytoplasm, with fine punctuated staining probably related to vesicular compartments (Figure 2B). Although further experiments are required to identify these compartments, our data suggest that Hoxal interacts with distinct modulators of a given pathway at the level of shared molecular platforms. Finally, some interactors such as MDFI, OGT, RBCK1, RBPMS or SPRY1 display various patterns of Hoxal interaction from cell to cell, possibly indicating dynamic partnerships depending on cell physiological state (Figure 3A and C).

Some links might be drawn between the molecular, cellular and developmental processes involving Hoxa1 and its interactors. LIMS1 for example is expressed in neural crest cells and plays an important role in neural crest development through TGF $\beta$ signaling [54]; in mouse, a downregulation of SPRY1 inhibits the rhombomere4-derived neural crest cells to colonize the $2^{\text {nd }}$ branchial arch [55]; RBPMS is expressed in the outflow tract of the developing heart [56], a territory colonized by Hoxa1 positive cells [57]. An important group of interactors consists in transcription factors. Some of them are known to be involved in embryonic patterning or cell fate decision (HOXD3, MDFI, PITX2 for example). In that regard, ZBTB16 (better known as PLZF) is a particularly relevant Hoxa1 interactor. It is expressed during hindbrain development at rhombomere boundaries and, like Hoxa1, has been proposed to control hindbrain segmentation [58]. Transcriptional coregulators, like the SET-domain histone methyl-transferase PRDM14 or the O-linked-N-acetylglucosamine (GlcNac) transferase OGT, have also been identified as Hoxa1 interactors which may contribute to Hoxa1-mediated gene regulation. Most significantly, OGT has recently been shown to be the homologue of the Drosophila Super sex combs (Sxc) protein. Sxc is associated to Polycomb complexes and is required for their ability to repress gene expression, including $H o x$ genes [59].

\section{Conclusions}

We presented here the first large-scale Hox interactome characterized so far. Although only a handful of interactors are known for other Hox proteins, some interactors identified here for Hoxal are shared with other Hox proteins [28]. PLSCR1 has been shown to contact HOXA9 and HOXB6, and HOXA9 is also contacted by TRIP6. RBPMS is able to interact with HOXA9 and HOXB9. These interactions, as well as other described here, underline that Hox proteins should be viewed not only as gene regulators, but also as components of signal transduction and modulation of cell-to-cell communication, cell adhesion and vesicular trafficking.

\section{Methods}

\section{Yeast two-hybrid screening}

The mouse Hoxal coding sequence was amplified from the pGIH327 expression plasmid[60] and cloned into pDONR-223 by Gateway BP recombinational reaction (attB1.1 primer: GGGGACAACTTTGTACAAAAAAGT TGGCATGAACTCCTTTCTGG; attB2.1 primer: GGG GACAACTTTGTACAAGAAAGTTGGGTAGTGGGAG GTAGTCAGAGTGTC; Invitrogen). By Gateway LR recombinational cloning, Hoxa1 was then transferred into pDEST-DB and pDEST-AD-CYH2 centromeric destination vectors [29] to code for Gal4 DNA binding domain (DB)-Hoxal and Gal4 activation domain (AD)Hoxa1 fusion proteins, respectively.

MAT $\mathbf{\alpha}$ Y8930 and MATa Y8800 yeast strains (genotype: trp1-901; leu2-3, 112; ura3-52; his3-200; gal4A; gal804; GAL2-ADE2; LYS2::GAL1-HIS3; met2::GAL7lacZ; $\left.c y h 2^{R}\right)$ were used for yeast two-hybrid $(\mathrm{Y} 2 \mathrm{H})$ screens. The DB-Hoxal coding construct was first tested for auto-activation by transforming it into the MAT $\mathbf{\alpha}$ Y8930 yeast strain and testing for expression of the HIS3 reporter gene in the absence of any AD-hORF fusion protein, on a solid synthetic complete medium lacking leucine and histidine (Sc-L-H) and supplemented with $1 \mathrm{mM} 3$-amino-triazol (3AT) [29]. The DB-Hoxa1 construct did not auto-activate.

High-throughput $\mathrm{Y} 2 \mathrm{H}$ screens were essentially performed as described [29]. Briefly, DB-Hoxal and ADHoxa1 vectors were transformed into MAT $\mathbf{\alpha}$ Y8930 or MATa Y8800 yeast strains, respectively. The DB-Hoxa1 construct in MAT $\mathbf{\alpha}$ Y8930 was mated with MATa Y8800 containing the AD-hORF library [27], and for the other configuration DB-hORFs library in MAT $\mathbf{\alpha}$ Y8930 were mated with AD-Hoxa1 in MATa Y8800. After overnight growth at $30^{\circ} \mathrm{C}$, diploid yeast cells were transferred to plates lacking histidine, leucine and tryptophan, supplemented with $1 \mathrm{mM}$ 3AT (Sc-L-T-H+3AT), to select for those with elevated expression of the GAL1-HIS3 reporter gene. 
Table 5 Functional classification of Hoxa1 interactors

\begin{tabular}{|c|c|c|c|}
\hline Function & Interactor & Function & Interactor \\
\hline Cell shape and migration & & Signal transduction (continued) & \\
\hline \multirow[t]{5}{*}{ Focal adhesion associated } & LIMS1 (PINCH1) & Other & MDFI \\
\hline & LPXN & & PDLMI7 (LMP-1) \\
\hline & MGAT5B & & PLZF \\
\hline & PDCD6IP (Alix) & & SMOC1 \\
\hline & TRIP6 & & \\
\hline \multirow[t]{4}{*}{ Cytoskeleton binding } & FHL5 (ACT) & Vesicular trafficking & PDCD6IP \\
\hline & LPXN & & Rab33A \\
\hline & PDCD6IP (Alix) & & SPRY2 \\
\hline & TRIP6 & & TRAPPC6A \\
\hline Cell junctions dynamics & LNX-2 & & TRIM23 (ARD1) \\
\hline \multirow[t]{2}{*}{ Signal transduction } & & Transcription regulation & FHL5 (ACT) \\
\hline & & & GRN precursor \\
\hline \multirow[t]{2}{*}{$\mathrm{BMP} / \mathrm{TGFb}$} & PDLIM7 (LMP-1) & & HOXA1 \\
\hline & RBPMS (Hermes) & & HOXD3 \\
\hline \multirow[t]{5}{*}{ Growth factors/RTK } & LIMS1 (PINCH1) & & HSFY1 \\
\hline & PDCD6IP (Alix) & & IKZF2 (Helios) \\
\hline & PLSCR1 & & LPXN \\
\hline & SPRY2 & & MDFI (I-mfa) \\
\hline & SPRY1 & & N4BP2L2 \\
\hline \multirow[t]{6}{*}{ TNFR family } & PDCD6IP (Alix) & & OGT \\
\hline & RBCK1 & & PITX2 \\
\hline & TRAF1 & & PLSCR \\
\hline & TRAF2 & & PRDM14 \\
\hline & TRIM23 (ARD1) & & RBCK1 \\
\hline & TRIP6 & & TRAPPC6A \\
\hline Wnt/b-catenin & MDFI & & TRIP6 \\
\hline \multirow[t]{4}{*}{ Focal adhesion/integrin } & LIMS1 (PINCH1) & & ZBTB16 (PLZF) \\
\hline & LPXN & & ZBTB32 (FAZF) \\
\hline & PDCD6IP (Alix) & & ZZZ3 \\
\hline & TRIP6 & & \\
\hline Notch & LNX-2 & Secreted protein/ECM & EFEMP2 \\
\hline \multirow[t]{7}{*}{ Protein kinases } & LGALS13 & & GRN \\
\hline & MDFI & & PDCD6IP \\
\hline & PLSCR1 & & SMOC1 \\
\hline & RBCK1 & & \\
\hline & RGS20 & Miscellaneous & KRT81 \\
\hline & SPRY2 & & KRTAP \\
\hline & TRIP6 & & PLSCR \\
\hline \multirow[t]{3}{*}{ GPCR } & RGS20 & & PLZF \\
\hline & ZBTB16 (PLZF) & & RAB33A \\
\hline & & & RBPMS \\
\hline
\end{tabular}




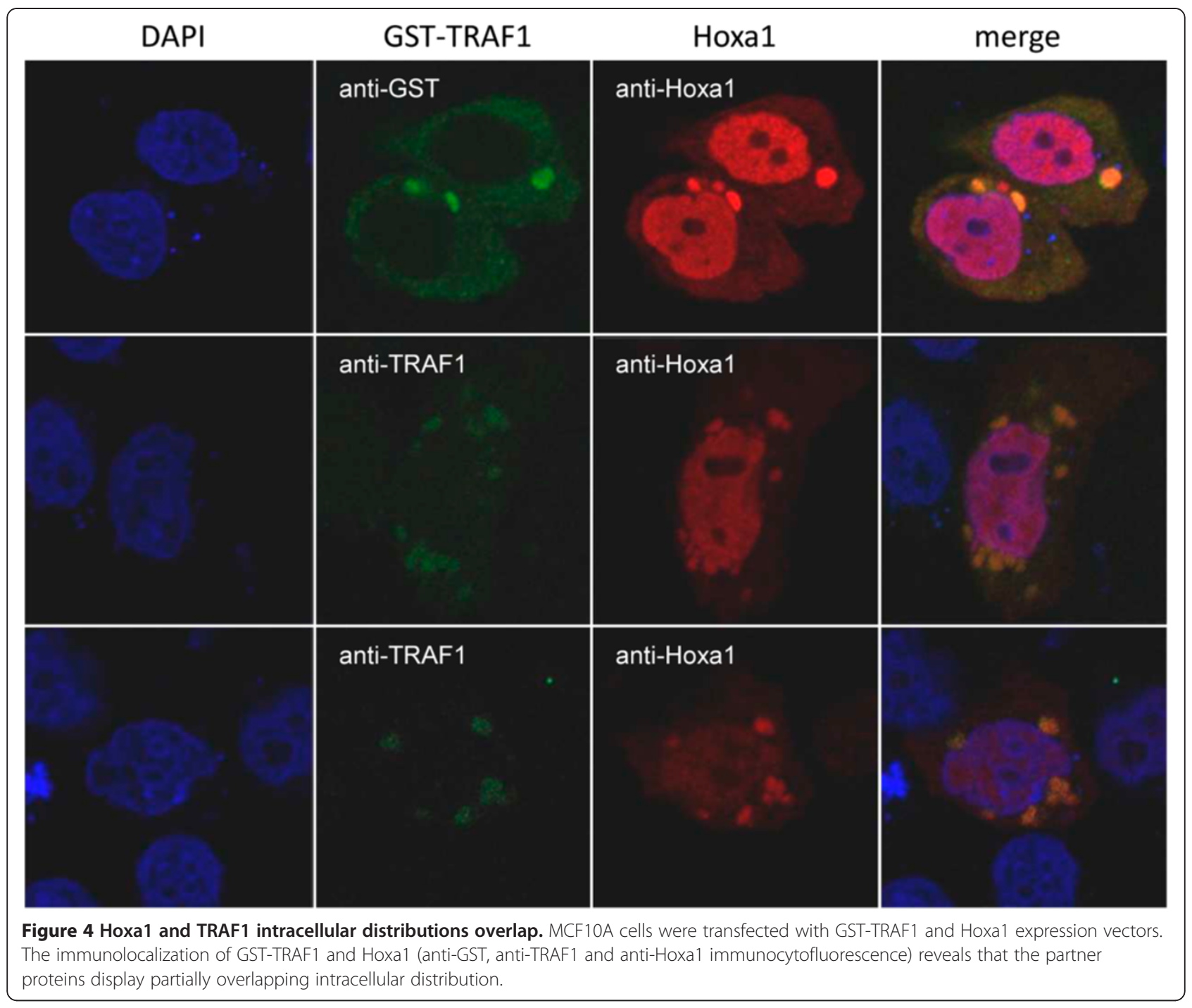

Positive colonies were picked, grown on Sc-L-T plates, and retested on $\mathrm{Sc}-\mathrm{L}-\mathrm{T}-\mathrm{H}$, as well as on medium lacking Adenine (Sc-L-T-A) and Sc-L-T-H-A+3AT, to select for colonies with high GAL1-HIS3 and GAL2-ADE2 reporter gene activity. To detect any spontaneous auto-activators arising in the course of the screen, positive colonies were transferred in parallel onto cycloheximide containing media $(\mathrm{Sc}-\mathrm{H}+\mathrm{CHX})$. Candidate colonies that grew on $\mathrm{Sc}-\mathrm{H}+\mathrm{CHX}$ were discarded.

The identities of candidate interacting pairs was determined by sequencing PCR products amplified directly from yeast cells using primers specific to Gal4DB and Gal4AD (DB primers: GGCTTCAGTGGAGACTGATA TGCCTC, GGAGACTTGACCAAACCTC TGGCG; AD primers: CGCGTTTGGAATCACTACAGGG, GGAGAC TTGACCAAACC TCTGGCG). PCR products were purified (Qiagen kit \# 28104) and sequenced.

The protein interactions from this publication have been submitted to the IMEx (http://www.imexconsortion.org) consortium through IntAct [pmid: 19850723] and assigned the identifier IM-15418.

\section{Co-precipitation assays}

The Hoxal coding sequence was transferred from the pDONR-223 Gateway ${ }^{\circledR}$ vector to pDEST-FLAG mammalian expression vector by Gateway ${ }^{\circledR}$ LR recombination reaction. Open reading frames coding for interactors from the hORFeome were cloned into a pDEST-GST mammalian expression vector by the same procedure.

COS7 and HEK293T cells were maintained in Dulbecco's modified Eagle's medium (DMEM) low glucose or high glucose respectively (Gibco/Invitrogen) supplemented with Glutamine, 10\% fetal bovine serum (Gibco/ Invitrogen), $100 \mathrm{IU} / \mathrm{ml}$ penicillin, and $100 \mu \mathrm{g} / \mathrm{ml}$ streptomycin (Gibco/Invitrogen). Cell lines were maintained at $37^{\circ} \mathrm{C}$ in a humidified, $5 \% \mathrm{CO}_{2}$ atmosphere. For transient transfection, $1.4 \times 10^{5}$ (COS7) or $4 \times 10^{5}$ (HEK293T) cells were plated into six-well plates. Twenty-four hours 
after plating, cells were transfected with TransFectin ${ }^{\text {тM }}$ reagent (BioRad). One and a half $\mu \mathrm{g}$ of pDEST-FLAGHoxa1 expression vector and $3 \mu \mathrm{g}$ of pDEST-GST-hORF were mixed with $250 \mu \mathrm{l}$ of serum-free medium and added to a mix of $1 \mu \mathrm{l}$ of TransFectin ${ }^{\mathrm{TM}}$ and $250 \mu \mathrm{l}$ of serum-free medium. Forty-eight hours after transfection, cells were lysed with Tris- $\mathrm{HCl}$ pH7.5 20mM, NaCl 120mM, EDTA $0.5 \mathrm{mM}$, NP40 0.5\%, glycerol $10 \%$ and Complete ${ }^{\mathrm{TM}}$ protease inhibitor (Roche).

Cell lysates were cleared by centrifugation for $5 \mathrm{~min}$ utes at 13,000 g. Cleared lysates were incubated overnight on gluthatione-agarose beads (Sigma \# G4510). Beads were cleared 3 times with the lysis buffer. Beads and third wash samples were then loaded on SDS-PAGE, transferred on nitrocellulose membrane and processed for detection of FLAG tagged proteins with an antiFLAG M2 antibody (Sigma \# F1804).

\section{Bimolecular Fluorescence Complementation assay (BiFC)} pDEST-VN173 and pDEST-VC155 plasmids were obtained by cloning sequences encoding $\mathrm{N}$-terminal residues $1-173$ and C-terminal residues 155-243 of the yellow fluorescent protein VENUS, respectively, within the pDEST-v1899FLAG vector instead of the 5' [KpnI|HindIII] 3xFLAGfragment (VN173F primers : GAGGTACCATGGTGAG CAAGGGCGAGGAGC, GGAGAAGCTTCTCGATGTTGT GGCGGATC; VC155 primers: AAGGTACCATGGCCGAC AAGCAGAAGAACGGC, GGAAAAGCTTCGTGGACCG GTGCTTGTACAGC).

The Hoxal coding sequence was transferred from the pDONR-223 Gateway $^{\circledR}$ vector to pDEST-VC155 mammalian expression vector by Gateway ${ }^{\circledR}$ LR recombination reaction. Open reading frames coding for interactors from the hORFeome were cloned into the pDEST-VN173 mammalian expression vector by the same procedure.

MCF10A cells were maintained at $37^{\circ} \mathrm{C}$ in a humidified $5 \% \mathrm{CO}_{2}$ atmosphere, in DMEM-F12+L-glutamine medium (Gibco/Invitrogen) supplemented with 5\% horse serum (Gibco/Invitrogen), $100 \mathrm{IU} / \mathrm{ml}$ penicillin (Gibco/Invitrogen), $100 \mu \mathrm{g} / \mathrm{ml}$ streptomycin (Gibco/Invitrogen), $100 \mathrm{ng} / \mathrm{ml}$ of cholera toxin (Gentaur), $20 \mathrm{ng} / \mathrm{ml}$ of human Epidermal Growth Factor (hEGF; Sigma), 500 $\mathrm{ng} / \mathrm{ml}$ hydroxycortisone (Sigma) and $10 \mu \mathrm{g} / \mathrm{ml}$ insulin (Sigma). For transfection, $3 \times 10^{5}$ cells were seeded on glass cover slips in 24-well plates. Twenty-four hours after plating, cells were transfected with TransFectin ${ }^{\text {Ts }}$ reagent (BioRad) or JetPRIME (Polyplus). For JetPRIME transfection, a total of $500 \mathrm{ng}$ of plasmid DNA were transfected per well: $100 \mathrm{ng}$ of pDEST-VN173-hORF, 20 ng of pDEST-VC155-Hoxa1 and 380 ng carrier DNA. DNA was mixed with $50 \mu \mathrm{l}$ JetPRIME buffer and $1 \mu \mathrm{l}$ of JetPRIME was added further. For TransFectin ${ }^{\mathrm{TM}}$-mediated transfection, $500 \mathrm{ng}$ of pDEST-VN173-hORF and $500 \mathrm{ng}$ of pDEST-VC155-Hoxa1 were mixed with $50 \mu \mathrm{l}$ of serum-free medium and added to a mix of $1 \mu$ of TransFectin $^{\mathrm{TM}}$ and $50 \mu \mathrm{l}$ of serum-free medium. Twenty-four hours after transfection, cells were fixed with $4 \%$ formaldehyde for 30 minutes, rinsed three times in PBS and once in TBS-0,1\% Triton X100. Glass cover slips were mounted in Vectashield ${ }^{\circledR}$-DAPI medium (Vector laboratories). BiFC were then analysed by confocal microscopy (LSM710, Zeiss, Jena, Germany; Plan-Apochromat 63x/1.40 Oil DIC M27 objective; Oil refraction index 1.5 imaging medium; PMT camera). Images were acquired by using the ZEN 2010 software, and subsequently processed with ZEN 2008 Light Edition.

\section{Immunocytolocalization}

COS7 and MCF10A cells were maintained, seeded on coverslips and transfected as described here above. Twenty four hours after transfection, cells were fixed with $4 \%$ formaldehyde for 30 minutes. Cells were further blocked with $10 \%$ low-fat milk in TBS-0.1\% Triton X100 solution for $45 \mathrm{~min}$ at room temperature, followed by overnight incubation in TBS-0.1\% Triton X100 solution at $4^{\circ} \mathrm{C}$, with a rabbit polyclonal anti-GFP (Invitrogen A11122, diluted 1/200), a mouse anti-GST (Sigma G1160, diluted 1/50), a mouse monoclonal anti-TRAF1 (Santa Cruz, sc-6253, diluted 1/50), or a rabbit polyclonal anti-Hoxa1 (Abcam ab64941, diluted 1/50), as primary antibodies. Cells were rinsed three times for 30 min in TBS-0.1\% Triton X100 solution and incubated for $45 \mathrm{~min}$ at room temperature with a goat anti-rabbit IgG-AF555 (Molecular Probes 4413, diluted 1/750), a goat anti-mouse IgG-FITC (SantaCruz sc-3699, diluted $1 / 100$ ), or a bovine anti-rabbit IgG-TRITC (SantaCruz sc-2367, diluted 1/100), as secondary antibodies. Cells were rinsed three times and glass cover slips were mounted in Vectashield ${ }^{\circledR}$-DAPI medium (Vector laboratories). Slides were then analysed by confocal microscopy (LSM710, Zeiss, Jena, Germany; Plan-Apochromat 63x/1.40 Oil DIC M27 objective; Oil refraction index 1.5 imaging medium; PMT camera). Images were acquired by using the ZEN 2010 software, and subsequently processed with ZEN 2008 Light Edition.

\section{Gene Ontology annotation and pathway analysis}

Gene Ontology (GO) annotations were downloaded from Entrez Gene (September 2009), pathway data from KEGG (September 2008) and Pathway Commons (September 2008) databases. From Pathway Commons, we analyzed the pathways originally annotated in NCINature[pid.nci.nih.gov] and Reactome [61].

Fisher's Exact Test was used to determine GO annotation and pathway enrichment of Hoxa1 direct targets, using the space of human proteins that have been tested 
in our $\mathrm{Y} 2 \mathrm{H}$ experiment, the human ORFeome v3.1 [27]. The corrected $p$-value was computed using the Benjamini-Hochberg multiple testing correction. We limited our results to GO annotations and pathways for which at least two Hoxa1 targets were annotated for.

To estimate the significance of indirect targets enrichment we ran 100,000 simulations for which the identity of the direct targets was randomized. The interactors of these targets were identified in an unbiased proteinprotein interaction network [28], to avoid study bias inherent to literature curation. Interactors belonging to each pathway were counted, and the resulting distribution compared to the observed counts. An empirical False Discovery Rate (FDR) determined the significance of the enrichment, with the FDR computed as the proportion of random trials giving at least the observed number of indirect targets in the analyzed pathway. The FDR was corrected for multiple testing using the Bonferroni correction. Pathways with a corrected FDR $<0.05$ and at least two observed proteins were considered significant.

\begin{abstract}
Abbreviations
TALE: Three Amino acid Loop Extension; TBP: TATA Binding Protein: HMG: High Mobility Group; CBP: CREB Binding Protein; Y2H: Yeast twohybrid; BMP: Bone Morphogenetic Protein; TGF: Tumor Growth Factor: TNF: Tumor Necrosis Factor; RTK: Receptor Tyrosine Kinase; BiFC: Bimolecular Fluorescence Complementation; DB DNA: Binding domain; AD: Activation Domain; 3AT: 3-Amino-Triazol; GO: Gene Ontology; FDR: False Discovery Rate; ORF: Open Reading Frame; GST: Glutathione S-Transferase; NCoR: Nuclear receptor Co-Repressor; SMRT: Silencing Mediator of Retinoic acid and Thyroid hormone receptor; HDAC: Histone Deacetylase; KAP: Keratin Associated Protein
\end{abstract}

\section{Competing interests}

The authors declare that they have no competing interests.

\section{Authors' contributions}

BL carried out most of the molecular biology, yeast two-hybrid and cell biology experiments, made a substantial contribution to data analysis and drafted the manuscript. JV contributed to the co-precipitation experiments and substantially contributed to the BiFC assay and immunocytofluorescent detection of proteins. SR and IB set up the BiFC assay and the BiFC controls. NS carried out the bioinformatics analyses. JCT helped in the yeast twohybrid screening and data interpretation. MV conceived and provided the materials required for the high-throughput yeast two-hybrid assay. RR conceived the study, significantly contributed to data interpretation and helped in drafting and revising the manuscript. All authors read and approved the final manuscript.

\section{Acknowledgments}

We are grateful to Michael Cusick and Matija Dreze for helpful comments on the manuscript. We are also grateful to Abdelmounaim Errachid (IMABIOL imaging platform) for technical assistance in confocal microscopy. We thank Samir Mérabet for providing us with plasmids coding for the VENUS VN173 and VC155 moieties and for helping us in setting up the BiFC assay. This work was supported by the Belgian Fund for Scientific Research (FNRS, FRSM grant 3.4.536.06F), the "Direction Générale des Technologies, de la Recherche et de l'Energie" of the Walloon Region (WALEOII grant n $\left.{ }^{\circ} 516054\right)$, the Fonds Spéciaux de Recherche (FSR) of the Université catholique de Louvain (UCL), and by US National Human Genome Research Institute grant R01-HG001715 to MV. BL and IB held a FRIA fellowship from the Belgian Fund for Scientific Research and a FSR grant from UCL. NS is supported by a return grant from Belspo (Belgian Federal Government). MV is a Chercheur Qualifié Honoraire of the Belgian Fund for Scientific Research.

\section{Author details}

${ }^{1}$ Molecular and Cellular Animal Embryology group, Life Sciences Institute (ISV), Université Catholique de Louvain, Louvain-la-Neuve 1348, Belgium. Bioinformatique des Génomes et des Réseaux (BiGRe), Université libre de Bruxelles, Bruxelles, Belgium. ${ }^{3}$ GIGA-R and Gembloux Agro Bio-Tech, Université de Liège, Liège 4000, Belgium. ${ }^{4}$ Center for Cancer Systems Biology (CCSB) and Department of Cancer Biology, Dana-Farber Cancer Institute, Boston, MA 02215, USA. ${ }^{5}$ Department of Genetics, Harvard Medical School, Boston, MA 02115, USA.

Received: 16 October 2012 Accepted: 16 October 2012

Published: 22 October 2012

\section{References}

1. Alexander T, Nolte C, Krumlauf R: Hox genes and segmentation of the hindbrain and axial skeleton. Annu Rev Cell Dev Biol 2009, 25:431-456.

2. limura T, Denans N, Pourquie O: Establishment of Hox vertebral identities in the embryonic spine precursors. Curr Top Dev Biol 2009, 88:201-234.

3. Narita Y, Rijli FM: Hox genes in neural patterning and circuit formation in the mouse hindbrain. Curr Top Dev Biol 2009, 88:139-167.

4. Wellik DM: Hox patterning of the vertebrate axial skeleton. Dev Dyn 2007, 236(9):2454-2463.

5. Mann R, Lelli K, Joshi R: Hox specificity unique roles for cofactors and collaborators. Curr Top Dev Biol 2009, 88:63-101.

6. Gehring WJ, Kloter U, Suga H: Evolution of the Hox gene complex from an evolutionary ground state. Curr Top Dev Biol 2009, 88:35-61.

7. Cillo C, Faiella A, Cantile M, Boncinelli E: Homeobox genes and cancer. Exp Cell Res 1999, 248(1):1-9.

8. Mark M, Rijli FM, Chambon P: Homeobox genes in embryogenesis and pathogenesis. Pediatr Res 1997, 42(4):421-429.

9. Hassan M, Saini S, Gordon J, van Wijnen A, Montecino M, Stein J, Stein G, Lian J: Molecular switches involving homeodomain proteins, HOXA10 and RUNX2 regulate osteoblastogenesis. Cells Tissues Organs 2009, 189(1-4):122-125.

10. Moens C, Selleri L: Hox cofactors in vertebrate development. Dev Biol 2006, 291(2):193-206.

11. Zhu A, Kuziora MA: Homeodomain interaction with the beta subunit of the general transcription factor TFIIE. J Biol Chem 1996, 271(35):20993-20996.

12. Um M, Li C, Manley JL: The transcriptional repressor even-skipped interacts directly with TATA-binding protein. Mol Cell Biol 1995, 15(9):5007-5016.

13. Chen $Y$, Knezevic V, Ervin V, Hutson R, Ward $Y$, Mackem S: Direct interaction with Hoxd proteins reverses Gli3-repressor function to promote digit formation downstream of Shh. Development 2004, 131(10):2339-2347.

14. Kataoka K, Yoshitomo-Nakagawa K, Shioda S, Nishizawa M: A set of Hox proteins interact with the Maf oncoprotein to inhibit its DNA binding, transactivation, and transforming activities. J Biol Chem 2001, 276(1):819-826.

15. Bai S, Shi X, Yang X, Cao X: Smad6 as a transcriptional corepressor. J Biol Chem 2000, 275(12):8267-8270

16. Li X, Nie S, Chang C, Qiu T, Cao X: Smads oppose Hox transcriptional activities. Exp Cell Res 2006, 312(6):854-864.

17. Zappavigna V, Falciola L, Helmer-Citterich M, Mavilio F, Bianchi ME: HMG1 interacts with HOX proteins and enhances their DNA binding and transcriptional activation. EMBO J 1996, 15(18):4981-4991.

18. Chariot A, van Lint C, Chapelier M, Gielen J, Merville MP, Bours V: CBP and histone deacetylase inhibition enhance the transactivation potential of the HOXB7 homeodomain-containing protein. Oncogene 1999, 18(27):4007-4014.

19. Shen W, Chrobak D, Krishnan K, Lawrence HJ, Largman C: HOXB6 protein is bound to CREB-binding protein and represses globin expression in a DNA binding-dependent, PBX interaction-independent process. $J$ Biol Chem 2004, 279(38):39895-39904.

20. Saleh M, Rambaldi I, Yang X-J, Featherstone MS: Cell signaling switches HOX-PBX complexes from repressors to activators of transcription mediated by histone deacetylases and histone acetyltransferases. Mol Cell Biol 2000, 20(22):8623-8633.

21. Topisirovic I, Kentsis A, Perez JM, Guzman ML, Jordan CT, Borden KLB: Eukaryotic Translation Initiation Factor 4E Activity Is Modulated by HOXA9 at Multiple Levels. Mol Cell Biol 2005, 25(3):1100-1112. 
22. Derossi D, Joliot AH, Chassaing G, Prochiantz A: The third helix of the Antennapedia homeodomain translocates through biological membranes. J Biol Chem 1994, 269(14):10444-10450.

23. Brunet I, Di Nardo A, Sonnier L, Beurdeley M, Prochiantz A: The topological role of homeoproteins in the developing central nervous system. Trends Neurosci 2007, 30(6):206-207.

24. Chisaka O, Musci TS, Capecchi MR: Developmental defects of the ear, cranial nerves and hindbrain resulting from targeted disruption of the mouse homeobox gene Hox-1.6. Nature 1992, 355(6360):516-520.

25. Lufkin T, Dierich A, LeMeur M, Mark M, Chambon P: Disruption of the Hox-1.6 homeobox gene results in defects in a region corresponding to its rostral domain of expression. Cell 1991, 66(6):1105-1119.

26. Zhang $X$, Zhu T, Chen Y, Mertani HC, Lee KO, Lobie PE: Human growth hormone-regulated HOXA1 is a human mammary epithelial oncogene. J Biol Chem 2003, 278(9):7580-7590.

27. Lamesch P, Li N, Milstein S, Fan C, Hao T, Szabo G, Hu Z, Venkatesan K, Bethel G, Martin P, Rogers J, Lawlor S, McLaren S, Dricot A, Borick H, Cusick ME, Vandenhaute J, Dunham I, Hill DE, Vidal M: hORFeome v3.1: a resource of human open reading frames representing over 10,000 human genes. Genomics 2007, 89(3):307-315.

28. Rual J-F, Venkatesan K, Hao T, Hirozane-Kishikawa T, Dricot A, Li N, Berriz GF, Gibbons FD, Dreze M, Ayivi-Guedehoussou N, et al: Towards a proteome-scale map of the human protein-protein interaction network. Nature 2005, 437(7062):1173-1178.

29. Dreze M, Monachello D, Lurin C, Cusick ME, Hill DE, Vidal M, Braun P: High-quality binary interactome mapping. Methods Enzymol 2010, 470:281-315.

30. Fernandez CC, Gudas L: The truncated Hoxa1 protein interacts with Hoxa1 and Pbx1 in stem cells. J Cell Biochem 2009, 106(3):427-443.

31. Phelan ML, Featherstone MS: Distinct HOX N-terminal arm residues are responsible for specificity of DNA recognition by HOX monomers and HOX.PBX heterodimers. J Biol Chem 1997, 272(13):8635-8643.

32. Phelan ML, Rambaldi I, Featherstone MS: Cooperative interactions between HOX and PBX proteins mediated by a conserved peptide motif. Mol Cell Biol 1995, 15(8):3989-3997.

33. Ashburner M, Ball CA, Blake JA, Botstein D, Butler H, Cherry JM, Davis AP, Dolinski K, Dwight SS, Eppig JT, et al: Gene ontology: tool for the unification of biology. The Gene Ontology Consortium. Nat Genet 2000, 25(1):25-29.

34. Kanehisa M, Araki M, Goto S, Hattori M, Hirakawa M, Itoh M, Katayama T, Kawashima S, Okuda S, Tokimatsu T, et al: KEGG for linking genomes to life and the environment. Nucleic Acids Res 2008, 36(Database):D480-D484.

35. Venkatesan K, Rual JF, Vazquez A, Stelzl U, Lemmens I, Hirozane-Kishikawa T, Hao T, Zenkner M, Xin X, Goh Kl, et al: An empirical framework for binary interactome mapping. Nat Methods 2009, 6(1):83-90.

36. Lee NK, Lee SY: Modulation of life and death by the tumor necrosis factor receptor-associated factors (TRAFs). J Biochem Mol Biol 2002, 35(1):61-66.

37. Lee SY, Choi Y: TRAF1 and its biological functions. Adv Exp Med Biol 2007, 597:25-31.

38. Dempsey PW, Doyle SE, He JQ, Cheng G: The signaling adaptors and pathways activated by TNF superfamily. Cytokine Growth Factor Rev 2003 14(3-4):193-209.

39. Li L, Bin L, Li F, Liu Y, Chen DC, Zhai Z, Shu H: TRIP6 is a RIP2-associated common signaling component of multiple NF-kappaB activation pathways. J Cell Sci 2005, 118(Pt3):555-563.

40. Mahul-Mellier A-L, Strappazzon F, Petiot A, Chatellard-Causse C, Torch S, Blot B, Freeman K, Kuhn L, Garin J, Verna J-M, et al: Alix and ALG-2 Are Involved in Tumor Necrosis Factor Receptor 1-induced Cell Death. J Biol Chem 2008, 283(50):34954-34965.

41. Odorizzi G: The multiple personalities of Alix. J Cell Sci 2006, 119(Pt 15):3025-3032.

42. Mason J, Morrison D, Basson M, Licht J: Sprouty proteins: multifaceted negative-feedback regulators of receptor tyrosine kinase signaling. Trends Cell Biol 2006, 16(1):45-54.

43. Cabrita MA, Christofori G: Sprouty proteins, masterminds of receptor tyrosine kinase signaling. Angiogenesis 2008, 11(1):53-62.

44. Schmidt MH, Hoeller D, Yu J, Furnari FB, Cavenee WK, Dikic I, Bogler O: Alix/ AIP1 antagonizes epidermal growth factor receptor downregulation by the Cbl-SETA/CIN85 complex. Mol Cell Biol 2004, 24(20):8981-8993.
45. Stasyk T, Schiefermeier N, Skvortsov S, Zwierzina H, Peranen J, Bonn GK, Huber LA: Identification of endosomal epidermal growth factor receptor signaling targets by functional organelle proteomics. Mol Cell Proteomics 2007, 6(5):908-922.

46. Lennartsson J, Wardega P, Engström U, Hellman U, Heldin C-H: Alix Facilitates the Interaction between c-Cbl and Platelet-derived Growth Factor Î2-Receptor and Thereby Modulates Receptor Down-regulation. J Biol Chem 2006, 281(51):39152-39158.

47. Sangadala S, Boden SD, Viggeswarapu M, Liu Y, Titus L: LIM Mineralization Protein-1 Potentiates Bone Morphogenetic Protein Responsiveness via a Novel Interaction with Smurf1 Resulting in Decreased Ubiquitination of Smads. J Biol Chem 2006, 281(25):17212-17219.

48. Sun Y, Ding L, Zhang H, Han J, Yang X, Yan J, Zhu Y, Li J, Song H, Ye Q: Potentiation of Smad-mediated transcriptional activation by the RNA-binding protein RBPMS. Nucl Acids Res 2006, 34(21):6314-6326.

49. Lipsky BP, Beals CR, Staunton DE: Leupaxin is a novel LIM domain protein that forms a complex with PYK2. J Biol Chem 1998, 273(19):11709-11713.

50. Pan S, Wang R, Zhou X, Corvera J, Kloc M, Sifers R, Gallick GE, Lin SH, Kuang J: Extracellular Alix regulates integrin-mediated cell adhesions and extracellular matrix assembly. EMBO J 2008, 27(15):2077-2090.

51. Pan S, Wang R, Zhou X, He G, Koomen J, Kobayashi R, Sun L, Corvera J, Gallick GE, Kuang J: Involvement of the conserved adaptor protein Alix in actin cytoskeleton assembly. J Biol Chem 2006, 281(45):34640-34650.

52. Cabezas A, Bache KG, Brech A, Stenmark H: Alix regulates cortical actin and the spatial distribution of endosomes. J Cell Sci 2005, 118(Pt 12):2625-2635.

53. Bai C-Y, Ohsugi M, Abe Y, Yamamoto T: ZRP-1 controls Rho GTPasemediated actin reorganization by localizing at cell-matrix and cell-cell adhesions. J Cell Sci 2007, 120(16):2828-2837.

54. Liang $X$, Sun $Y$, Schneider J, Ding J-H, Cheng H, Ye M, Bhattacharya S, Rearden A, Evans S, Chen J: Pinch1 Is Required for Normal Development of Cranial and Cardiac Neural Crest-Derived Structures. Circ Res 2007, 100(4):527-535.

55. Trokovic N, Trokovic R, Partanen J: Fibroblast growth factor signalling and regional specification of the pharyngeal ectoderm. Int J Dev Biol 2005, 49(7):797-805.

56. Gerber W, Yatskievych TA, Antin PB, Correia KM, Conlon RA, Krieg PA: The RNA-binding protein gene, hermes, is expressed at high levels in the developing heart. Mech Dev 1999, 80(1):77-86.

57. Makki N, Capecchi MR: Hoxa1 lineage tracing indicates a direct role for Hoxa1 in the development of the inner ear, the heart, and the third rhombomere. Dev Biol 2010, 341(2):499-509.

58. Ivins S, Pemberton K, Guidez F, Howell L, Krumlauf R, Zelent A: Regulation of Hoxb2 by APL-associated PLZF protein. Oncogene 2003, 22(24):3685-3697.

59. Gambetta MC, Oktaba K, Muller J: Essential Role of the Glycosyltransferase Sxc/Ogt in Polycomb Repression. Science 2009, 325(5936):93-96.

60. Remacle S, Shaw-Jackson C, Matis C, Lampe X, Picard J, Rezsohazy R: Changing homeodomain residues 2 and 3 of Hoxa 1 alters its activity in a cell-type and enhancer dependent manner. Nucleic Acids Res 2002, 30(12):2663-2668

61. Matthews L, Gopinath G, Gillespie M, Caudy M, Croft D, de Bono B, Garapati P, Hemish J, Hermjakob H, Jassal B, et al: Reactome knowledgebase of human biological pathways and processes. Nucleic Acids Res 2009, 37(Database):D619-D622.

doi:10.1186/1471-213X-12-29

Cite this article as: Lambert et al:: Protein interactions of the transcription factor Hoxa1. BMC Developmental Biology 2012 12:29. 